\title{
The Health Status and Genetic Variations of the Bivalve, Pinctala radiata Affected by Environmental Pollution
}

\section{Karolin Kamel Abdul-Aziz*}

Zoology Department, Faculty of Science, Damanhour University, Damanhour, Egypt

\begin{abstract}
The bivalve shellfish Pinctala radiate is a popular edible food for Alexandria local communities. In an attempt to track the quality of marine water of two different locations along Alexandria coast of Egypt, we measured the RNA/DNA ratio and acetyl cholinesterase (AChE) activity in the haemolymph of this organism. The study showed an average ratio for RNA-DNA of 3.3, arranged as follows; 4.34 at El-Max $>2.8$ at Miami localities. These results suggest that the coastal water of Alexandria is considered as unpolluted with examined insecticides in this research.
\end{abstract}

Keywords: Water quality - RNA; DNA ratio-Acetyl cholinesterase -Eco-toxicology

\section{Introduction}

Alexandria is the second largest city of Egypt and one includes a wide variety of industries which comprises 100 large factories and about 260 smaller ones. Untreated sewage and waste waters are discharged annually from large numbers of outlets into Alexandria coastal area through local sewage system. Marine mollusks such as oysters are exposed to multiple stressors [1]. Marine pollutants produce multiple consequences at the organism, population and ecosystem levels, affecting organ functions. Among such pollutants, carcinogenic compounds are of particular interest and tumors have indeed been detected in marine shellfish [2]. DNA alterations induced by chemical and physical agents include single and double strand breakages, DNA-DNA cross links, and DNA-protein cross links. Cholinesterases (ChEs) represent a well-known class of serine hydrolases. They are considered ubiquitous enzymes whose physiological function is to remove acetylcholine from synaptic clefts. AchE is thought to be mainly involved in neurotransmitter hydrolysis. ChEs have been found as polymorphic enzymes in invertebrates. Two forms of ChEs have been identified in Ostrea edulis and Mytilus spp. Recent transplant studies have demonstrated that peroxisome proliferation is a rapid (i.e. two days) and reversible response to pollution by PAHs and PCBs in mussels. When organisms are exposed to organic xenobiotics, an increase in volume and number of peroxisomes is also observed. These changes are often associated with an increase of enzyme activities involved in fatty acid oxidation, such as acetyle Co-A oxidase (Aox). Transports of xenobiotics have been found in aquatic invertebrates. The stress protein response was studied as an indicator of water quality in gills and striated muscle tissues of fathead minnows Pimephales promelas exposed to a wide range of concentrations of sodium arsenite for various time intervals. The stress protein response in gills was elicited rapidly, occurring by ( $2 \mathrm{hrs}$.) exposure at $25 \mathrm{mg} / \mathrm{L}$. The response was tissue specific. In gills, synthesis and accumulation rates of $20,40,70,72$ and $74 \mathrm{KDa}$ proteins were significantly increased compared to controls. In muscle, 20, 30, 68, 70, and $90 \mathrm{KDa}$ proteins also showed significantly increased synthesis and accumulations. The use of molecular markers has become widely accepted as a valuable tool [3]. Williams et al. [4] were the first to describe RAPD markers; based on the amplification of random DNA segments with single primers of arbitrary nucleotide sequence. These polymorphisms, simply detected as DNA segments which are amplified from one sample but not the others and are visible as the presence or absence of particular RAPD bands, and are inherited in a Mendelian fashion and can be used to construct genetic maps in a variety of species [5]. Polymorphism results from mutation or re-arrangements at or between oligonucleotide primer binding sites in a genome. These polymorphisms are usually separated on agarose gels and visualized by ethidium bromide staining. Such polymorphisms behave as dominant genetic markers.

By the early of fifties, heavy industries were established in Alexandria metropolitan areas of Egypt. Chemicals, metal products and textiles are the most prominent branches in Egypt [6]. The worst industrial waste liquids are those heavily laden with heavy metals. Such waters endanger public health through the direct use as well as through feeding on fish that live in the polluted streams [7]. The metropolitan area of Alexandria accommodates a multitude of industries in the vicinity of surface waters. Out of 1243 industrial plants, 57 were identified as major sources of marine pollution either directly or indirectly via Lake Mariut $[8,9]$. Oysters may experience rapid and extreme temperature fluctuations in their habitats with a change in body temperature as large as $10-20^{\circ} \mathrm{C}$ within a few minutes $[10,11]$.

Molluscs have successfully adapted to fresh and marine water [12]. Marine molluscs have been found to be highly responsive indicator species in the investigation of pollutant toxicology. Marine molluscs are extensively used in biomonitoring studies due to their ability to concentrate metallic pollutants $[13,14]$. The sensitive aquatic environment is suffering of pollution that affects both quantity and quality of benthic invertebrate biodiversity. Marine molluscs such as oysters are exposed to multiple stressors such as varying levels of trace metals which may interactively affect their physiology $[1,15,16]$ studied the population dynamics of the Pinctada radiata from the Mediterranean sea. The levels of contaminant accumulated in the tissues of Pinctada radiata (Bivalve) has been used to indicate the degree of chemical contamination in the environment. Industrial wastes are considered to be the major source of pollution in Egypt. Also it is reported that, Pinctada radiata could be used as an indicator species for heavy metals

*Corresponding author: Karolin Kamel Abdul-Aziz, Zoology Department Faculty of Science, Damanhour University, Damanhour, Egypt, E-mail: k.kamel2002@yahoo.com

Received April 02, 2012; Accepted April 25, 2012; Published April 27, 2012

Citation: Abdul-Aziz KK (2012) The Health Status and Genetic Variations of the Bivalve, Pinctala radiata Affected by Environmental Pollution. J Environ Anal Toxicol 2:138. doi:10.4172/2161-0525.1000138

Copyright: ( 2012 Abdul-Aziz KK. This is an open-access article distributed under the terms of the Creative Commons Attribution License, which permits unrestricted use, distribution, and reproduction in any medium, provided the original author and source are credited. 
accumulation studies. Element concentrations in molluscs at the same location differ between different individual and different animals in the same community at the same trophic level could accumulate pollutants differently [17]. According to Viarengo (1993) [18], the mechanism of metal sequestration in membrane-limited vesicles may represent a general strategy for metal cation homeostasis. $\mathrm{Cu}$ granules are involved in the metabolism of hemocynin in gastropods.

Metal exposure leads to various types of DNA damage. DNA damage has been observed in two forms DNA strand break and DNA oxidation. The amount of DNA strand breakage may correlate with the amount of free radicals generated. Toxic metals are capable of disturbing the natural oxidation/reduction balance in cells through various mechanisms stemming from their own complex oxidation/ reduction reactions with endogenous oxidants and effects on cellular antioxidant systems. The resulting oxidative stress causes lipid peroxidation, protein alteration and DNA damage which may indicate levels of metals toxicity. Ecological interactions and genetic changes in quantitative trails are integral parts of an ongoing evolutionary process. Understanding this interaction between evolution and ecology by means of estimates of genetic variation and natural selection is the core of an ecological genetics approach.

\section{Aim of The Work}

The present work aims to investigate environmental pollution by heavy metals on Pinctala radiate that may affect both health status and genetic variation.

\section{Materials and Methods}

Mediterranean mussels (Pinctala radiata) collected from El-Max and Miami. All the animal experiments were reviewed and approved by Animal Care Committee in the faculty of Science, Damanhour University. Twenty naïve mussels were sampled and the foot, gills and hemocytes were removed and immediately freeze clamped and stored in liquid nitrogen for further analyses. Routine tests and determination were conducted on animal samples and tissues. These tests are GGT, AchE, RNA , RNA/DNA ratio ... etc.

The pesticides determined were determined by the chromatographs of the pesticides using gas chromatography (GC) and high performance liquid chromatography (HPLC). The stock solutions for carbamate and OP pesticides were prepared separately by dissolving pure pesticide standards in acetonitrile. The stock solutions of OC and synthetic pyrethroid pesticides were prepared with $n$-hexane. The stock solutions were mixed well and then serially diluted with acetonitrile or nhexane depending on the pesticide type to the appropriate concentrations in $\mathrm{mg} / \mathrm{L}$. For each pesticide, there were 3 concentrations with $1 / 2$ serial dilution added to fishery products.

\section{Gamma-glutamyltransferase (GGT)}

Gamma-glutamyltransferase (GGT) catalyzes the transfer of the glutatmyl group from $\gamma$-glutamyl-3-carboxy-4-nitroanilide to glycylglycine, liberating 3-carboxy-4-nitroaniline, Groff et al. [19]. The catalytic concentration is determined from the rate of 3-carboxy4-nitroaniline formation. The molar absorbance $(\varepsilon)$ of 3-carboxy-4nitroaniline at $\lambda=410 \mathrm{~nm}$ is 7908 and at $\lambda=405 \mathrm{~nm}$ is 9900 , the light path (I) was $1 \mathrm{~cm}$, the total reaction volume $\left(\mathrm{V}_{\mathrm{t}}\right)$ was $1.0 \mathrm{ml}$

\section{Determination of acetyl cholinesterase (AchE)}

This was carried according to [20] Panteghini et al. Acetyl cholinesterase (AchE) catalyzes the hydrolysis of benzoylcholine to choline and benzoic acid. The catalytic concentration is determined from the rate of quinine-imine formation, measured at $\lambda=500 \mathrm{~nm}$, by means of the choline oxidase and peroxidase coupled reactions

$$
\text { Benzoylcholine }+\mathrm{H}_{2} \mathrm{O} \stackrel{\mathrm{CHE}}{\longrightarrow} \text { choline }+ \text { Benzoic acid. }
$$

Choline $+\mathrm{O}_{2} \stackrel{\text { choline oxidase }}{\longrightarrow}$ Betaine $+2 \mathrm{H}_{2} \mathrm{O}_{2}$.

$2 \mathrm{H}_{2} \mathrm{O}_{2}+$ phenol +4 -Amino atipyrine $\stackrel{\text { POD }}{\longrightarrow}$ quinonemine $+\mathrm{H}_{2} \mathrm{O}$

The atypical isoenzyme of cholinesterase $(\Delta \mathrm{A})$ can be estimated indicating the inhibition of enzyme activity in the presence of dibucaine and expressed in percent. The cholinesterase concentration in the sample is calculated using the following general formula:

$$
\Delta \mathrm{A} / \min \times \frac{\mathrm{Vt} \times 10^{6}}{\varepsilon \times 1 \times \mathrm{Vs}}=\mathrm{U} / \mathrm{L}
$$

The molar absorbance $(\varepsilon)$ of the dye at $\lambda=500 \mathrm{~nm}$ is 5340 , the light path (1) is $1 \mathrm{~cm}$, the total reaction volume $\left(\mathrm{V}_{\mathrm{t}}\right)$ is 1.51 , the sample volume (Vs) is 0.01 , and $1 \mathrm{U} / \mathrm{L}$ are $0.0166 \mu \mathrm{kat} / \mathrm{L}$. The following formulas are deduced for the calculation of the catalytic concentration.

\section{Determination of RNA/DNA}

\section{Extraction procedure of RNA and DNA:}

I. Reagents: Chloroform analytical grade, Methanol analytical grade, Potassium hydroxide $(0.3 \mathrm{~N})$, Perchloric acid $(0.5 \mathrm{~N})$

II. Procedures: One hundred mg dry tissue was homogenized in a blender for 2 minutes in a mixture of $0.1 \mathrm{ml}$ chloroform and $2.0 \mathrm{ml}$ methanol. 1.0 chloroform was added, followed by homogenization for an additional 1 minute: Then $1.0 \mathrm{ml}$ distilled water was and homogenized for $1 \mathrm{~min}$. the whole mixture is centrifuged at $10.000 \mathrm{rpm}$ and $4^{\circ} \mathrm{C}$, for 10 minutes then the supernatant was discarded and the sediment was washed with $2 \mathrm{ml}$ of chloroform: methanol: water (1:2: 0.8) and centrifuged at $10.000 \mathrm{rpm}$ and $4^{\circ} \mathrm{C}$ for minutes. The precipitate was washed once with ether and centrifuged at $10.000 \mathrm{rpm}$ for 15 minutes at $4^{\circ} \mathrm{C}$. The precipitate was treated with $3.0 \mathrm{ml}, 0.3 \mathrm{~N} \mathrm{KOH}$ at $37^{\circ} \mathrm{C}$ for 20 hours. To the ice-cold tubes $2 \mathrm{ml} 0.5 \mathrm{~N}$ perchloric acid added, and left for 30 minutes. After centrifugation at 10.000 r.p.m. and $4^{\circ} \mathrm{C}$ for 10 minutes, the supernatant, fraction I, was taken for the ribonucleic acids (RNA) determination by the Orcinol reaction. The precipitate was incubated in $3 \mathrm{ml}$ $0.5 \mathrm{~N}$ perchloric acid for 20 minutes at $90^{\circ} \mathrm{C}$. The suspension was centrifuged at 5.000 r.p.m. for 10 minutes at $0^{\circ} \mathrm{C}$. The supernatant, Fraction II, containing the deozyribonucleic acids was removed for the chemical colorimetric assay.

The foot tissue was treated as described by Bligh and Dyer [21] for total lipid extraction then as described by [22] Keleti and Lederer for RNA and DNA extraction. The steps can be summarized as follows:

III. Estimation of ribonucleic acids (RNA): The color forming reaction involved liberation of pentoses from the ribonucleic acids, conversion of pentoses to furfural by heating with strong acid and reaction of furfural with orcinol to yield a mixture of blue-green condensation products.

Stock Standard RNA Solution: Ten milligrams of RNA (Yeast core RNA, Sigma Co.) were dissolved in $100 \mathrm{ml}$ solution composed of $0.3 \mathrm{~N} \mathrm{KOH}$ and $0.5 \mathrm{~N} \mathrm{HClO}_{4}(3: 2, \mathrm{~V} / \mathrm{V})$. One milliliter of fraction I was added to $3 \mathrm{ml}$ reagent A (Glycylglycine $206.25 \mathrm{mmol} / \mathrm{L}$, sodium hydroxide $130 \mathrm{mmol} / \mathrm{L}, \mathrm{pH}$ 7.9). The solution was mixed thoroughly by vortex and then the tubes were covered with a marble and placed 
in a pan of vigorously boiling water for 20 minutes. The tubes were removed from the bath and left to cool at room temperature. A Blank was prepared the same way using $1 \mathrm{ml}$ mixture of $0.3 \mathrm{~N} \mathrm{KOH}$ and 0.5 $\mathrm{N} \mathrm{HClO}_{4}(3: 2, \mathrm{~V} / \mathrm{V})$. The absorbance of each sample was determined spectrophotometrically at $\lambda=665 \mathrm{~nm}$ against blank.

I. RNA Standard Curve: Different volumes of stock solution contained, $0.01,0.02$, up to $0.1 \mathrm{mg} \mathrm{RNA} / \mathrm{ml}$ were treated as above. The absorbance at $\lambda=665 \mathrm{~nm}$ has been plotted against micrograms of RNA. The content of RNA in $1 \mathrm{ml}$ extract was determined by finding its absorbance and using the standard curve. This value was multiplied by a factor 5 in order to find the total amount or RNA in the sample, and then expressed as $\mu \mathrm{g} / 100 \mathrm{~g}$ dry tissue.

Estimation of deoxyribonucleic acids (DNA): This method was used for quantitative estimation of DNA after separation using the previous extraction procedure.

DNA Stock standard solution: Ten $\mathrm{mg}$ of DNA (highly polymerized Calf thymus, from Sigma Co.) were dissolved in $100 \mathrm{ml}$ $0.5 \mathrm{~N} \mathrm{HClO}_{4}$.

One milliliter of fraction II was added to $1 \mathrm{ml}$ reagent $\mathrm{C}$, ten milliliters of reagent A was diluted with $10 \mathrm{ml}$ of Reagent B ( $\gamma$ Glutamyl-3-carboxy-4-nitroanilide $32.5 \mathrm{mmol} / \mathrm{L}$.), in a test tube, and placed in a boiling water bath for 10 minutes then removed and cooled under running tap water to room temperature. The contents of the tube was extracted $3 \times 2 \mathrm{ml}$ amyl acetate to remove the interfering color (the phase was separated by centrifugation, the amyl acetate layer was discarded). The aqueous layer was read at $\lambda=490 \mathrm{~nm}$ against the blank $\left(1 \mathrm{ml} 0.5 \mathrm{~N} \mathrm{HClO}_{4}\right.$ ).

DNA Standard Curve: Different volumes of stock solution contained, $0.01,0.02$, up to $0.1 \mathrm{mg} \mathrm{DNA} / \mathrm{ml}$ were treated as mentioned above; the absorbance at $\lambda=490 \mathrm{~nm}$ has been plotted against micrograms of DNA. The concentration of DNA presented in $1 \mathrm{ml}$ extract was determined through its absorbance and using the standard curve. The total amount of DNA in the sample was obtained by multiplying the previous value by a factor 3 . The concentration of DNA expressed in micrograms per $100 \mathrm{~g}$ dry tissue.

RNA/DNA ratio: This ratio was calculated by dividing the RNA value by the value of DNA for the same sample.

\section{Heavy metal determination}

The heavy metal concentrations, in $\mu \mathrm{g} / \mathrm{L}$, were performed by Perkin Elmer 2380 flame atomic absorption spectrophotometer using standard methods.

\section{Results}

Cholinesterase concentration level, per $100 \mathrm{~g}$ sample, in the haemolymph of Pinctada radiata. The levels of cholinesterase activity followed the arrangement of Miami $>$ El Max, Table 1. The concentration level of Albumin in the haemolymph of Pinctada radiata showed different values as arranged geographically as; 3.26 , and $3.66 \mathrm{~g}$ at Miami and El Max; respectively. The highest value was recorded at El Max as; $3.66 \mathrm{~g}$. The mean average of levels followed the arrangement of El Max > Miami. The concentration level, per $100 \mathrm{~g}$ sample, of globulin of haemolymph of Pinctada radiata differed geographically as: 1.48 and $1.04 \mathrm{~g}$ at Miami and El Max. The highest concentration was recorded at Miami as $1.48 \mathrm{~g}$ while the lowest value was recorded at El Max, as, $1.04 \mathrm{~g}$. The mean value of different levels followed the arrangement as
Miami > El Max. The concentration level of gammaglutamyl transferase (GGT) of haemolymph of Pinctada radiata followed different activity levels as geographically as; 65.0, and 61.0 U/L; at Miami and El Max; respectively. The highest value was recorded at Miami as; $65.0 \mathrm{U} / \mathrm{L}$. The level of GGT had different arrangements as Miami > El Max, Table 1.

The RNA-DNA ratio was compared in the same manner, Table 2. The ratio for El Max region was greater than that of Miami.

The level of copper in the seawater ranged between 0.9 to 0.68 ; at $(\mathrm{t})=5.87$, at El Max to Miami, respectively; while the level of lead in the seawater ranged between 2.12 to 0.32 , at $(\mathrm{t})=9.93^{*}$, at El Max to Miami; respectively, whereas the level of cadmium in the seawater ranged between 0.83 to 0.37 at $(\mathrm{t})=19.7^{*}$, at El Max and Miami; respectively, Table 3 . All values of heavy metals differed significantly between the two locations.

The level of Aldrin in the seawater ranged between 0.04 to 0.00 , at $(\mathrm{t})=23.519^{*}$, at El Max to Miami; respectively. The level of Endrin in the seawater ranged between 0.03 to 0.02 at $(t)=0.68$ at El Max and Miami; respectively, where as, the PP-DDT was not reported in both locations (Table 4).

The correlation between the biochemical parameters in the two sites (studied groups):

\section{At El Max}

Acetylcholinesterase (AchE) was significantly negatively correlated with Albumin and GGT in the haemolymph of Pinctada radiata as $r=-0.307$ and $r=-0.006$ whereas AChE was positively correlated with globulin in the haemolymph of bivalve as, $r=0.413$. The concentration level of Albumin was positively correlated to globulin in the haemolymph of the bivalve as; $r=0.144$ while it was negatively correlated with GGT as $r=-0.517$. The concentration level of globulin in the haemolymph of the bivalve was negatively correlated with GGT as $r=-0.134$, Table 5 .

\section{At Miami}

The concentration level of AchE in the haemolymph of the bivalve was highly positively correlated with Albumin and GGT as $\mathrm{r}$ $=0.595$ and $\mathrm{r}=0.457$; respectively. While it was negatively correlated with globulin as $r=-0.08$. The concentration level of albumin in the haemolymph of the bivalve was positively correlated with globulin and highly correlated with GGT as $r=0.122$ and $r=0.899^{*}$. The level of globulin was positively correlated with GGT as $r=0.188$, Table 5 . were:

The correlations between heavy metals in the two studied groups

\section{At El Max}

Copper levels in the seawater was negatively correlated to that of lead and positively correlated with cadmium as $r=-0.397$ and $r$ $=-0.009$; respectively. Whereas, lead in the seawater was negatively correlated with $\mathrm{Cd}$ as $\mathrm{r}=-0.288$, Table 6 .

\section{At Miami}

Copper levels in the seawater was negatively correlated with lead levels and positively correlated with cadmium ones as $\mathrm{r}=-0.175$ and $\mathrm{r}=$ 0.015 ; respectively. Lead level was negatively correlated with cadmium as $\mathrm{r}=-0.394$, Table 6 .

Correlation between pesticides in the two studied groups were: 
Citation: Abdul-Aziz KK (2012) The Health Status and Genetic Variations of the Bivalve, Pinctala radiata Affected by Environmental Pollution. J Environ Anal Toxicol 2:138. doi:10.4172/2161-0525.1000138

Page 4 of 7

\section{At El Max}

Aldrin levels in the seawater was negatively correlated with Endrin and positively correlated with PP-DDT as $r=-0.306$ and $r=0.655$; respectively. Endrin was negatively correlated with PP-DDT as $\mathrm{r}=$ $-0.778^{*}$, Table 7 .

\section{At Miami}

Aldrin and Endrin did not report any correlation, Table 7.

Correlation between RNA/DNA ratio with the biochemical parameters, heavy metals and pesticides showed that:

The RNA/DNA ratio in the haemolymph of the bivalve Pinctada radiata is positively correlated with AChE in El Max and Miami as $r=0.205$ and 0.499 ; respectively, Table 8 . The RNA/DNA ratio in the haemolymph of the bivalve Pinctada radiata is highly positively correlated with albumin at $\mathrm{El} \mathrm{Max}$ as $\mathrm{r}=0.729^{*}$ while it is negatively correlated with albumin at Miami as $r=-0.229$. The RNA/DNA ratio in the haemolymph of the bivalve Pinctada radiata is positively correlated with globulin at Miami as $\mathrm{r}=0.275$ and negatively correlated with globulin at El-Max as $r=-0.108$. The RNA/DNA ratio in the haemolymph of the bivalve Pinctada radiata is negatively correlated with GGT at El Max and Miami; as $r=-0587$ and $r=-0.392$, respectively. The RNA/DNA ratio in the haemolymph of the bivalve Pinctada radiata is negatively correlated with $\mathrm{Cu}$ at El Max as $\mathrm{r}=$ -0.395 and positively correlated with $\mathrm{Cu}$ in the seawater at Miami as $\mathrm{r}=$ 0.140 . The RNA/DNA ratio in the haemolymph of the bivalve Pinctada radiata is negatively correlated with lead in the seawater in both sites as $r=-0.067$ and $r=-0.426$; respectively. The RNA/DNA ratio in the haemolymph of the bivalve Pinctada radiata is highly positively correlated with cadmium in the seawater at El-Max as $\mathrm{r}=0.824$ and negatively correlated with cadmium in seawater at Miami as $r=-0.337$. The RNA/DNA ratio in the haemolymph of the bivalve Pinctada radiata is positively correlated with Aldrin at El Max as $r=0$. 120. The RNA/DNA ratio in the haemolymph of the bivalve Pinctada radiata is highly positively correlated with Endrin at El Max as $\mathrm{r}=0.7758^{\star}$ and negatively correlated with Endrin at Miami as $r=-0.389$. The RNA/ DNA ratio in the haemolymph of the bivalve Pinctada radiata is negatively correlated with PP-DDT at El Max as $\mathrm{r}=-0.341$, Table 8.

\section{Discussion}

The mechanisms by which environmental salinity selects for population differentiation have been proposed by [23] Hilbish et al. The final products of amino acids degradation in general metabolic processes are; ammonia, urea and uric acid. The replacement of amino acid losses takes place by protein degradation [24]. It is reported that the aspartate aminotransferase activities in various tissues of Tilapia nilotica fish were markedly inhibited due to their exposure to barium. Hilbish et al. [23] has postulated the effect of the environmental salinity on the free amino acids. Since these conditions producing a hyperosmotic stress resulted in faster accumulation of free amino acids used to regulate cell volume. This is apparently reversed under reduced salinity conditions, since excess free amino acids are produced by protein catabolism only to be excreted away in maintaining cell volume, these changes may result in population differentiation at the biochemical genetic level [25]. El-Sayed [24] working on Tilapia nilotica reported that; there were an increase in muscular tissue content of free amino acids, may account for the enhancement of protein catabolism and/or protein degradation due o the salinity and/or heavy metals constituting the plastic and Battery manufacturing, liquid waste to be excreted away in order to maintain cell volume as results of hypersomatic stress effect.

\begin{tabular}{llll}
\hline & El-Max & Miami & $t(p)$ \\
\hline AChE & & & $4.388^{*}(0.008)$ \\
Mean \pm SD & $426.40 \pm 18.41$ & $464.08 \pm 5.47$ & \\
\hline $\begin{array}{l}\text { Albumin } \\
\text { Mean } \pm \text { SD }\end{array}$ & $3.62 \pm 0.04$ & $3.21 \pm 0.09$ & $9.751^{*}(<0.001)$ \\
\hline $\begin{array}{l}\text { Globulin } \\
\text { Mean } \pm \text { SD }\end{array}$ & $1.03 \pm 0.01$ & $1.47 \pm 0.01$ & $59.908^{*}(<0.001)$ \\
\hline GGT & & & $10.922^{*}(<0.001)$ \\
Mean \pm SD & $61.60 \pm 0.42$ & $64.92 \pm 0.54$ &
\end{tabular}

t: Student t-test

*: Statistically significant at $p \leq 0.05$

Table 1: Comparison between the two studied groups according to AchE, albumin globulin and GGT, U/L.

\begin{tabular}{llll}
\hline RNA-DNA Ratio & El-Max & Miami & $t(p)$ \\
\hline Mean \pm SD & $4.36 \pm 0.36$ & $2.78 \pm 0.17$ & $8.970^{*}(<0.001)$
\end{tabular}

t: Student t-test

*: Statistically significant at $p \leq 0.05$

Table 2: Comparison between the two studied groups according to RNA-DNA Ratio, U/L.

\begin{tabular}{llll}
\hline & El-Max & Miami & $t(p)$ \\
\hline $\begin{array}{lll}\text { Copper } \\
\text { Mean } \pm \text { SD }\end{array}$ & $0.90 \pm 0.02$ & $0.68 \pm 0.08$ & $5.870^{*}(0.003)$ \\
\hline Lead & & & $9.033^{*}(0.001)$ \\
Mean \pm SD & $2.12 \pm 0.45$ & $0.32 \pm 0.02$ & \\
\hline $\begin{array}{l}\text { Cadmium } \\
\text { Mean } \pm \text { SD }\end{array}$ & $0.83 \pm 0.03$ & $0.37 \pm 0.04$ & $19.700^{*}(<0.001)$
\end{tabular}

t: Student t-test

*: Statistically significant at $p \leq 0.05$

Table 3: Comparison between the two studied groups according to Copper, Lead and Cadmium, $\mu \mathrm{g} / \mathrm{L}$

\begin{tabular}{llll}
\hline & El-Max & Miami & $\mathrm{t}(\mathrm{p})$ \\
\hline $\begin{array}{lll}\text { Aldrin } \\
\text { Mean } \pm \text { SD }\end{array}$ & $0.04 \pm 0.00$ & $0.00 \pm 0.00$ & $23.519^{*}(<0.001)$ \\
\hline $\begin{array}{l}\text { Endrin } \\
\text { Mean } \pm \text { SD }\end{array}$ & $0.03 \pm 0.00$ & $0.02 \pm 0.04$ & $0.684(0.531)$ \\
\hline PP-DDT & & & $1.633(0.178)$ \\
Mean \pm SD & $0.00 \pm 0.00$ & $0.00 \pm 0.00$ & \\
\hline
\end{tabular}

t: Student t-test

* : Statistically significant at $p \leq 0.05$

Table 4: Comparison between the two studied groups according to Aldrin, Endrin and PP-DDT, U/L.

\begin{tabular}{|c|c|c|c|c|c|}
\hline \multirow{7}{*}{$\frac{\sum_{\frac{1}{W}}^{\times}}{W}$} & \multirow{3}{*}{ AchE } & & Albumin & Globulin & GGT \\
\hline & & $r$ & -0.307 & 0.413 & -0.006 \\
\hline & & $p$ & 0.615 & 0.489 & 0.992 \\
\hline & \multirow{2}{*}{ Albumin } & $r$ & & 0.144 & -0.517 \\
\hline & & $p$ & & 0.818 & 0.372 \\
\hline & \multirow{2}{*}{ Globulin } & $r$ & & & -0.134 \\
\hline & & $p$ & & & 0.830 \\
\hline \multirow{6}{*}{ 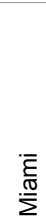 } & \multirow{2}{*}{ AchE } & $r$ & 0.595 & -0.080 & 0.457 \\
\hline & & $p$ & 0.290 & 0.899 & 0.439 \\
\hline & \multirow{2}{*}{ Albumin } & $r$ & & 0.122 & $0.899^{+}$ \\
\hline & & $p$ & & 0.845 & 0.038 \\
\hline & \multirow{2}{*}{ Globulin } & $r$ & & & 0.188 \\
\hline & & $p$ & & & 0.762 \\
\hline
\end{tabular}

r: Pearson coefficient

*: Statistically significant at $p \leq 0.05$

Table 5: Correlation between the biochemical parameters in the two studied groups, U/L. 
Citation: Abdul-Aziz KK (2012) The Health Status and Genetic Variations of the Bivalve, Pinctala radiata Affected by Environmental Pollution. J Environ Anal Toxicol 2:138. doi:10.4172/2161-0525.1000138

Page 5 of 7

The final products of amino acids degradation in general metabolic processes are; ammonia, urea and uric acid. The replacement of amino acid losses takes place by protein degradation [24]. Hilbish et al. [23] has postulated the effect of the environmental salinity on the free amino acids. Since these condition producing a hyperosmotic stress, resulted in faster accumulation of free amino acids used to regulate cell volume. This is apparently reversed under reduced salinity conditions, since excess free amino acids are produced by protein catabolism only to be excreted away in maintaining cell volume, these changes may result in population differentiation at the biochemical genetic level [25]. $\mathrm{He}$ added that, protein polymorphism have been used to investigate the genetic structure of natural populations of diversity of marine invertebrates.

It has become very important that the precise detection of genotoxic effects should be an essential part of any genetic toxicology screening program for food. Such compounds can cause a potential increase of mutagenicity and carcinogenicity. Mutagenicity can increase the frequency of delirious mutants in next generation. Several genotoxic assay are now available, but it is often difficult to decide which are the most suitable for screening the genotoxic effect of a given chemical because there are considerable differences both between the sensitivity of the test methods and between the effects of different classes of chemicals. Schut et al. [26] stated that the accuracy of genetic similarity estimates based on molecular data depends on several variable factors such as the number of markers analyzed, their distribution over the genome and the accurancy in scoring the markers. Toxic metals are capable of disturbing the natural oxidation reduction balance in the cells through various mechanisms stemming from their own complex redox reactions with endogenous oxidants and effects on cellular antioxidant systems. The resulting oxidative stress causes DNA damage which may contribute to metals ' toxicity. The amount of RNA in cells is directly proportional to the protein synthesis rate. Therefore, the ratio of RNA/DNA is index of the metabolic rate of cells [27]. The higher GC content primer should revealed that there was no clear relation between GC content of the primers and the number of amplified products. The highest number of amplified fragments (17) was obtained by primer G5 which has $60 \%$ GC content, while primers A6 and A9 which have $70 \%$ GC content generated lower number of fragments (13 and 12 ). Lefebvre et al. [28] stated that low molecular distances were systematically associated with low phenotypeic distances. Graner et al. and Russell et al. [29,30] reported that genetic similarity estimates based on molecular markers data have been described as a direct measure of genetic similarity. Powell et al.[31] stated that although different types of markers are capable of detecting single nucleotide mutations as well as insertion/ deletions, their relative sensitivity to these types of mutations is expected to vary, because each exhibits its own sensitivity and levels of resolution of differences in band size. Differences between genotypes are either direct or indirect representation of differences at the DNA level and are therefore, expected to provide information about genetic relationships. Gagné et al. [32] reported increased DNA damage in two species of freshwater Mussels (Elliptio complanata and Dreissene polymorpha). The range of metal concentrations is generally below acute thresholds in coastal areas, where recognition of chronic sub lethal effects is more relevant. Experimental studies were carried out on Mytilus galloprovincialis exposed in aquarium (5 days) to different concentrations of $\mathrm{Cd} \mathrm{Cl} 2$. $\mathrm{Cd}$ induced increase of DNA damage. A marked decrease and or increase in DNA and RNA contents might have resulted from pollutant induced mutations at the DNA levels in the sites to which specific transcription regulating proteins must bind or at the RNA level in

\begin{tabular}{|c|c|c|c|c|}
\hline & & & Lead & Cadmium \\
\hline \multirow[b]{4}{*}{$\stackrel{\underset{\mathbb{\pi}}{\Sigma}}{\sum^{2}}$} & \multirow{2}{*}{ Copper } & $\mathrm{R}$ & -0.397 & 0.009 \\
\hline & & $P$ & 0.508 & 0.989 \\
\hline & \multirow[b]{2}{*}{ Lead } & $\mathrm{R}$ & & -0.288 \\
\hline & & $\mathrm{P}$ & & 0.638 \\
\hline \multirow{4}{*}{ 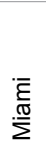 } & \multirow{2}{*}{ Cooper } & $\mathrm{R}$ & -0.175 & 0.015 \\
\hline & & $P$ & 0.778 & 0.981 \\
\hline & \multirow{2}{*}{ Lead } & $\mathrm{R}$ & & -0.394 \\
\hline & & $P$ & & 0.512 \\
\hline
\end{tabular}

r: Pearson coefficient

Table 6: Correlation between heavy metals in the two studied groups.

\begin{tabular}{|c|c|c|c|c|}
\hline \multirow{5}{*}{$\begin{array}{l}\underset{x}{\infty} \\
\sum^{\infty}\end{array}$} & \multirow{3}{*}{ Aldrin } & & Endrin & PP DDT \\
\hline & & $r$ & -0.306 & 0.655 \\
\hline & & $p$ & 0.617 & 0.231 \\
\hline & \multirow{2}{*}{ Endrin } & $r$ & & -0.778 \\
\hline & & $p$ & & 0.121 \\
\hline \multirow{3}{*}{ 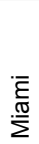 } & \multirow{2}{*}{ Aldrin } & $r$ & - & - \\
\hline & & $p$ & - & - \\
\hline & Endrin & $r$ & & - \\
\hline
\end{tabular}

Table 7: Correlation between pesticides in the two studied groups.

\begin{tabular}{|c|c|c|c|}
\hline \multirow{3}{*}{ AchE } & & El Max & Miami \\
\hline & $r$ & 0.205 & 0.499 \\
\hline & $\mathrm{p}$ & 0.741 & 0.392 \\
\hline \multirow{6}{*}{ Albumin } & $r$ & 0.729 & -0.229 \\
\hline & $\mathrm{p}$ & 0.162 & 0.711 \\
\hline & & -0.108 & 0.275 \\
\hline & & 0.863 & 0.654 \\
\hline & & -0.587 & -0.392 \\
\hline & $\mathrm{p}$ & 0.298 & 0.514 \\
\hline \multirow{2}{*}{ Copper } & $r$ & -0.395 & 0.140 \\
\hline & $p$ & Globulin & $r$ \\
\hline \multirow{2}{*}{ Lead } & $r$ & & $\mathrm{p}$ \\
\hline & $\mathrm{p}$ & GGT & $r$ \\
\hline \multirow{2}{*}{ Cadmium } & $r$ & 0.824 & -0.337 \\
\hline & $\mathrm{p}$ & 0.086 & 0.580 \\
\hline \multirow{2}{*}{ Aldrin } & $r$ & 0.120 & - \\
\hline & $p$ & 0.848 & - \\
\hline \multirow{2}{*}{ Endrin } & $r$ & 0.758 & -0.389 \\
\hline & $\mathrm{p}$ & 0.138 & 0.518 \\
\hline \multirow{2}{*}{ PP DDT } & $r$ & -0.341 & - \\
\hline & $\mathrm{p}$ & 0.574 & - \\
\hline
\end{tabular}

Table 8: Correlation between RNA/ DNA ratio with the biochemical parameters heavy metals and pesticides.

the ribosome-binding sites for introns excision in m-RNA. Mutations that disrupt these sites have the potential to change the expression of a gene in terms of the amount of product expressed. Mutations at such regulatory sites will affect the amount of protein products of a gene [33]. Deoxyribose nucleic acid (DNA) carries the genetic material of each cell and is present in the nucleus in fixed quantity [34]. He added that ribose nucleic acid (RNA) is present in variable quantity in the nucleus and cytoplasm and is concerned with the transfer of the genetic code of the nuclear DNA into the body of the cell and the creation of actual sequences of amino acids in the synthesis of new protein. It was reported that mussels collected from populations subjected to different levels of heavy metal pollution, demonstrating that the rate 
Citation: Abdul-Aziz KK (2012) The Health Status and Genetic Variations of the Bivalve, Pinctala radiata Affected by Environmental Pollution. J Environ Anal Toxicol 2:138. doi:10.4172/2161-0525.1000138

Page 6 of 7

of protein synthesis was significantly decreased in various tissues of mussels, and the RNA synthesis were similarly decreased [35]. Mussels are sensitive towards genotoxins and are widely used in biomonitoring programs [36,37]. Exposure of mussels in the field to water polluted by different mixtures of genotoxic contaminants induces DNA alterations [38]. The response of genotoxicity biomarkers, despite the high inter-individual variability, showed a good discriminatory power allowing the identification of stations along a pollution gradient, and confirmed the sensitivity of these methods for coastal biomonitoring. It is suggested that, mussels accumulate higher concentrations of persistent pollutants, such as heavy metals and express higher genetic damage frequency as a result of time integrated response to cumulative exposure. Caged mussels showed higher strand breaks probably as the result of very recent exposure to genotoxic agents. Current awareness of the potential hazards of pollutants in the aquatic environment has stimulated much interest in the use of oysters, as indicators for monitoring environmental mutagens.

\section{Summary}

Most of oysters including Pinctala radiata; can survive in polluted water which may affect the genetic material of these animals particularly if this pollution results from the presence of heavy metals, agrochemical or insecticides. Consequently, this study was carried out to evaluate the changes that may occur to the genetic characters of oyster namely; Pinctada radiata, as they may be changed due to exposing to the pollutants during their life. It must be taken into consideration that there are other factors which may contribute to these alterations. Since a long period of time, the Mediterranean Sea receives a very huge amount of different waste water (industrial, agricultural, and municipal), which may carry the heavy metals and the insecticides.

\section{References}

1. Sokolova IM (2004) Cadmium effects on mitochondrial function are enhanced by elevated temperatures in a marine poikilotherm, Crassostrea virginica Gmelin (Bivalvia:Ostereidae). J Exp Biol 207: 2639-2648.

2. Bolognesi C, Landini E, Roggieri P, Fabbri R, Viarengo A (1999) Genotoxicity biomarkers in the assessment of heavy metal effects in mussels: experimental studies. Environ Mol Mutagen 33: 287-292.

3. El Shenhab NAA (2003) Genetic analysis in some Citrus Accessions using PCR-based molecular markers. M.Sc. Thesis.Fac. Agric. Cairo Univer.pp.178.

4. Williams JGK, Kubelik AR, Livak KJ, Rafalski JA, Tingey SV (1990) DNA polymorphism amplified by arbitrary primers are useful as genetic markers. Nuc Aci Res 18: 6531-6535.

5. Welsh J, McClelland M (1990) Fingerprinting genomes using PCR with arbitrary primers. Nuc Aci Res 18: 7213-7218.

6. Hamza A, Gallup J (1982) Assessment of environmental pollution in Egypt: Case study of Alexandria Metropolitan. WHO 56-61.

7. Abdel Dayem S (1994) Water quality issues in Egypt. Indian-Egyptian Study Days on the Environment, Cairo, 9-20 October, pp. 81-92.

8. Hamza A (1983) Management of industrial hazardous water in Egypt. Industry and Environment. UNEP, Special Issue, No. 4.

9. Hussein I, Abdel-Shafy, Raouf OA (2002) Water Issue in Egypt: Resouurces, Pollution and Protection Endeavors. CEJOEM 8 :3-21.

10. Sokolova IM, Bock C, Portner HO (2000) Resistance to freshwater exposure in White Sea Littorina spp. I. Anaerobic metabolism and energetic. J Comp Physiol B 170: 91-103.

11. Sokolova IM, Boulding EG (2004) A neutral DNA marker suggests that paralle physiological adaptations to open shore and salt marsh habitats have evolved more than once within two different species of gastropods. Mar Biol 145: 133147
12. Webber HH, Thurman HV (1991) "Marine Biology". Harper Collins College Publishers, New York.

13. Goldberg ED (1986) The mussel watch concept. Envir Monitor Assessm 7 91-103.

14. Brayan G (1980) Quantitative Aquatic Biological Indicators. Barking, Essex, UK: Applied Science Publishers, Ltd., London 15: 589-590.

15. Yassien MH (1998) Biological and ecological studies on the pearl oyster Pinctada radiata (Mollusca, Lamellibranchia) from the Red Sea, with special reference to its tolerance to water pollution. Ph.D. Thesis, Fac. Sci. Ain Shams Univ.

16. Yassien MH, Abdel-Razek FA, Kilada RW (2000) Growth estimates of the pearl oyster, Pinctada radiata, from the Eastern Mediterranean, Egypt. J Aquat Biol and Fish., 4:105-118.

17. El Moselhy KhM, Yassien MH (2005) Accumulation patterns on heavy metals in venus clams, Paphia undulate (Born, 1780) and Gafrarium pectinatum (Linnaeus, 1758), from Lake Timsah , Suez Canal, Egypt. Egyptian Journal of aquatic Research 31:1.

18. Viarengo A, Nott JA (1993) Mechanisms of heavy metal cation homeostasis in marine invertebrates. Comp Biochem Physiol 104: 355-372.

19. Groff JL, Harp JB, DiGirolamo M (1993) Simplified enzymatic assay of angiotensin-converting enzyme in serum, Clin Chem 39: 400-404.

20. Panteghini M, Bonora R, Pagani $F$ (1986) "Evaluation of a new method for cholinesterase determination," Clin Biochem 19: 161-165.

21. Bligh EG, Dyer WJ (1959) A rapid method of total lipid extraction and purification. Can J Biochem Physiol 37: 911-917.

22. Keleti G, Lederer WH (1974) Handbook of Micro-methods for the Biological Sciences., Van Nostrand Reinhold Co, 450 W. 33rd St, New York, N Y 10011.

23. Hilbish TJ, Deaton LE, Koehn RK (1982) Effect of an allozyme polymorphism on regulation of cell volume. Nature 298: 688-689.

24. El Sayed AA (1990) Biochemical studies on Tilapia nilotica exposed to raw and treated plastic and electronic manufacturing. M.Sc. Thesis, Fac. Sci., Alex University.

25. Burton RS (1983) Protein polymorphism and genetic differentiation of marine invertebrate populations. Mar Biol Letters 4: 193-206.

26. Schut JW, Stam P (1997) Association between relationship measures based on AFLP markers, pedigree data and morphological traits in barley . Teor App Genet 95: 1161-1168.

27. Garcia-Meunier P, Martel C, Pigeot J, Chevalier G, Blanchard G, et al. (2002) Recent invasion of the Japanese oyster drill along the French Atlantic Coast: Identification of specific molecular markers that differentiate Japanese, Ocinebrellus inornatus, and European, Ocenebra erinacea, oyster drills. Aquatic Living Resour 15: 67-71.

28. Lefebvre V, Goffinet B, Chauvet JC, Caromel B, Signoret P, et al. (2001) Evaluation of genetic distances between pepper inbred lines for cultiva protection purposes: comparison of AFLP, RAPD and phenotypic data. Theor Appl Genet 102: 741-750.

29. Graner A, Ludwing WF, Melchinger AE (1994) Relationships among European barley germplasm. II Comparison of RFLP and pedigree data. Crop Sci 43: 1199-1205.

30. Russell JR, Fuller JD, Macaulay M, Hatz BG, Jahoor A, et al. (1997) Direct comparison of levels of genetic variation among barley accessions of detected by RELP, AFLP, SSR and RAPD. Theor Appl Genet 95: 714-722.

31. Garcia AF, Benchimol L, Barbosa1 M, Geraldi I,Souza L, et al. (1996) The comparison of RFLP, RAPD, AFLP and SSR (microsatellite) markers for germ plasma analysis. Mol Breed 2: 225-238.

32. Gagné F, Blaise C, Aoyama I, Luo R, Gagnon C, et al. (2002) Biomarker study of municipal effluent dispersion plumme in two species of freshwater mussels. Environ Toxicol 17: 149-159.

33. Khair-Allah DA, Matta CA, Yousif WB, Sorour JM, Shonouda ML, et al. (2006) Impact of pollution on the water bug Sphaerodema urinator (Dofour, 1833) inhebting Lakes Mariut and Edku. Ph.D. Fac. Sci. Alexandria university, Egypt.

34. Love RM (1980) The chemical biology of Fishes. New York, Academic Press, $2,547 p$. 
Citation: Abdul-Aziz KK (2012) The Health Status and Genetic Variations of the Bivalve, Pinctala radiata Affected by Environmental Pollution. J Environ Anal Toxicol 2:138. doi:10.4172/2161-0525.1000138

Page 7 of 7

35. Viarengo A, Pertica M, Mancinelli G, Palmero S, Zanicchi G, et al. (1982) Evaluation of general and specific stress indices in mussels collected from populations subjected to different levels of heavy metal pollution. Mar Environ Res 6: 235-243.

36. Viarengo A, Canesi L (1991) Mussels as biological indicators of pollution. Aquaculture 94: 225-243.
37. O Connor TP (2002) National distribution of chemical concentrations in mussels and oysters in the USA. Marine Environ Res 53: 117-143.

38. Izquierdo JI, Machado G, Ayllon F, d'Amico VL, Bala LO, et al. (2003) Assessing pollution in coastal ecosystems: a preliminary survey using the micronucleus test in the mussel Mytilus edulis, Ecotoxicol Environ Saf 55: 24-29. 